\author{
Military Technical College \\ Kobry Elkobbah, Cairo, \\ Egypt.
}

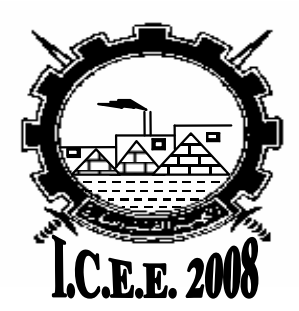

$4^{\text {th }}$ International Conference
On

Chemical \& Environmental Engineering

27-29 May 2008

\title{
UTILIZATION OF CARBON DIOXIDE FOR POLLUTION CONTROL BY REFORMING
}

\author{
Fakeeha, A.H. , Soliman M.A., AL-Fatish A.S
}

\begin{abstract}
Environmental pollution and global warming are of great concern for life existence. Hazards to health and change in climate are among these effects that are caused by the global warming and pollution. Many gases cause these phenomena such as carbon dioxide that comes from burning processes and manufacturing processes as well as fermentation processes. Any method of utilizing such gas will be helpful, especially if this method converts it into useful products. This paper will deal with reforming methods to utilize carbon dioxide and convert it into synthesis gas that is considered as feed for chemical and petrochemical industries.
\end{abstract}

\section{KEYWORDS:}

Carbon dioxide, Reforming, Synthesis gas, Pollution control 


\section{INTRODUCTION}

Utilization of carbon dioxide (CO2) has become an important global issue due to the significant and continuous rise in atmospheric $\mathrm{CO} 2$ concentrations. Technology should be developed to capture large amounts of $\mathrm{CO}_{2}$ and sequester it deep underground or under the seafloor. The utilization of $\mathrm{CO}_{2}$ as a chemical feedstock is useful but is hindered by cost of the energy requirement for chemical conversion and by the limited market size for the anticipated products.

The monoethanolamine (MEA) absorption, membrane separation, pressure swing adsorption, and $\mathrm{O}_{2} / \mathrm{CO}_{2}$ input system are being studied as methods for carbon dioxide capture. One of the recent achievements [ 1 ]is a CO2-selective highcapacity adsorbent which was developed using mesoporous molecular sieve MCM-41 and polyethylenimine (PEI). The MCM41-PEl adsorbent has higher adsorption capacity than either PEI or MCM-41 alone and can be used as highly CO2-selective adsorbent for gas mixtures without the pre-removal of moisture because it even enhances $\mathrm{CO} 2$ adsorption capacity $\mathrm{O}_{2} / \mathrm{CO}_{2}$ fuel combustion system is a new method devised to obtain flue gas with high percentage of $\mathrm{CO} 2$. Here the flue gases are partially recycled and combined with oxygen.

The approaches for enhancing $\mathrm{CO} 2$ utilization may include one or more of the following [2]: (1) for applications that do not require pure $\mathrm{CO} 2$, develop effective processes for using the $\mathrm{CO} 2$-concentrated flue gas from industrial plants or CO2-rich resources without $\mathrm{CO} 2$ separation; (2) for applications that need pure CO2, develop more efficient and less-energy intensive processes for separation of $\mathrm{CO} 2$ selectively without the negative impacts of co-existing gases such as $\mathrm{H} 2 \mathrm{O}, \mathrm{O} 2$, and $\mathrm{N} 2$; (3) replace a hazardous or less-effective substance in existing processes with $\mathrm{CO} 2$ as an alternate medium or solvent or co-reactant or a combination of them; (4) make use of $\mathrm{CO} 2$ based on the unique physical properties as supercritical fluid or as either solvent or anti-solvent; (5) use $\mathrm{CO} 2$ based on the unique chemical properties for $\mathrm{CO} 2$ to be incorporated with high 'atom efficiency' such as carboxylation and carbonate synthesis; (6) produce useful chemicals and materials using CO2 as a reactant or feedstock; (7) use $\mathrm{CO} 2$ for energy recovery while reducing its emissions to the atmosphere by sequestration; (8) recycle CO2 as C-source for chemicals and fuels using renewable sources of energy; and (9) convert $\mathrm{CO} 2$ under either biochemical or geologic-formation conditions into "new fossil" energies.

Bulk chemicals already produced from $\mathrm{CO}_{2}$ include urea to make nitrogen fertilizers, salicylic acid as a pharmaceutical ingredient, and polycarbonate-based plastics. Carbon dioxide also could be used more widely as a solvent. For example, supercritical $\mathrm{CO}_{2}$ (the state existing at $31.0{ }^{\circ} \mathrm{C}$ and $72.8 \mathrm{~atm}$ ) offers advantages in terms of product purification, and environmental issues for synthesizing fine chemicals and pharmaceuticals. Other routes for using $\mathrm{CO}_{2}$ include oil and gas recovery, enhanced agricultural production, and ponds of genetically modified algae that can convert power-plant $\mathrm{CO}_{2}$ into biodiesel. 
A paper by Ritter [ 3 ] summarizes the papers presented at a recent American Chemical Society meeting (Chicago 2007);

1- Research is being carried out to produce formic acid by hydrogen reduction of carbon dioxide,

2-. Cyclic carbonates can be obtained directly from an olefin and $\mathrm{CO}_{2}$. Cyclic carbonates are commercially Important compounds and are used as electrolytes in lithium batteries, as polar solvents, and as intermediates for producing polycarbonate and fine chemicals. Carbonates are useful and often greener substitutes for toxic phosgene $\left(\mathrm{COCl}_{2}\right)$ and dimethyl sulfate in many chemical reactions. They also serve as solvents, especially in medicines and cosmetics, and they are used as electrolytes in lithium-ion batteries.

3- Geoffrey W. Coates and his group at Cornell University developed catalysts to incorporate $\mathrm{CO}_{2}$ into polymers. Two successes are $\beta$-diiminate zinc acetate and salen cobalt carboxylate complexes. These catalysts promote alternating copolymerization of various epoxides with $\mathrm{CO}_{2}$ to make biodegradable aliphatic polycarbonates.

The polymers, which contain $30-50 \% \quad \mathrm{CO}_{2}$ by weight, have gas-barrier and degradation properties that make them attractive for food packaging, foamcasting to make automotive parts, and electronics processing applications. The polymers also can be used to replace propylene oxide segments in polyurethane foams, which would help cut costs. The foams are used for insulation and seat cushions, among other applications.

4- $\quad$ Research is being carried out on "artificial photosynthesis," which in the case of $\mathrm{CO}_{2}$ involves designing photocatalyst systems that use solar energy to reduce the gas to hydrocarbons. The aim is to produce large quantities of methanol or hydrocarbon fuels directly from captured $\mathrm{CO}_{2}$. This approach does not only help to reduce global warming but also solve the problem of depleting fossil-fuel reserves.

5- Palladium can catalyze reduction of $\mathrm{CO}_{2}$ to $\mathrm{CO}$ in an electrochemical cell, a reaction that partially mimics photosynthesis.

The ultimate goal would be to develop a system that converts $\mathrm{CO}_{2}$ directly to methanol or a similar compound that could be used as a fuel. Huang et al. [4] used modified Zinc Oxide for the Direct Synthesis of Propylene Carbonate from Propylene Glycol and Carbon dioxide in the presence of acetonitrile, which acted as not only the solvent but also the dehydrating reagent in the reaction. Ammonium carbonate was added into the reaction to significantly elevate the selectivity of propylene carbonate. Dimethyl carbonate can be synthesized from methanol and $\mathrm{CO}_{2}$ by using propylene carbonate as a recyclable intermediate.

The environmental problems related to fuel transportation become more serious recently. Therefore, much attention has been paid to the synthetic fuel (FischerTropsch oil, for example) which does not contain sulfur at all. In addition, methanol is a candidate as a hydrogen source for the fuel cell vehicle, and dimethyl ether will be a superclean diesel fuel. Methanol (Eq. (1)) and Fischer-Tropsch long chain 
hydrocarbons ( Eq. (2)) are synthesized from the synthesis gas with $\mathrm{H}_{2} / \mathrm{CO}=2$, and dimethyl ether( Eq. (3)) is synthesized from that with $\mathrm{H}_{2} / \mathrm{CO}=1$ [10]

$\mathrm{CO}+2 \mathrm{H}_{2} \rightarrow \mathrm{CH}_{3} \mathrm{OH}$

$n \mathrm{CO}+2 n \mathrm{H}_{2} \rightarrow\left(\mathrm{CH}_{2}\right)_{n}+n \mathrm{H}_{2} \mathrm{O}$

$3 \mathrm{CO}+3 \mathrm{H}_{2} \rightarrow \mathrm{CH}_{3} \mathrm{OCH}_{3}+\mathrm{CO}_{2}$

Synthesis gas (syngas), a mixture of $\mathrm{H}_{2}$ and $\mathrm{CO}$, is an important feedstock. With a suitable $\mathrm{H} 2 / \mathrm{CO}$ ratio, it can be used to produce methanol, synthetic fuels, hydrocarbon chemicals, and oxygenated chemicals. Moreover, the hydrogen content can be utilized both in the chemical industry and for the generation of electric energy from fuel cells.

In general, there are three processes for production of synthesis gas; steam reforming, $\mathrm{CO}_{2}$ reforming and partial oxidation of methane or natural gas. Various combination of these methods are possible; for example auto-thermal reforming which is a combination of steam or $\mathrm{CO}_{2}$ reforming with partial oxidation Another example is tri-reforming of methane to synthesize syngas with desirable $\mathrm{H}_{2} / \mathrm{CO}$ ratios by simultaneous oxy- $\mathrm{CO}_{2}$-steam reforming of methane. Another name for trireforming is oxyforming [5]

\section{Steam Reforming of Methane}

The main reaction for steam reforming is:

$$
\mathrm{CH}_{4}+\mathrm{H}_{2} \mathrm{O} \leftrightarrow \mathrm{CO}+3 \mathrm{H}_{2} \quad \Delta \mathrm{H}_{298 \mathrm{~K}}=206 \mathrm{~kJ} / \mathrm{mol}
$$

The reaction is catalyzed by $\mathrm{Ni}$-based catalysts, although more expensive metals such as $\mathrm{Pd}$ and $\mathrm{Pt}$ are more effective. Being endothermic and reversible, the reaction is carried out at high temperature $\left(900^{\circ} \mathrm{C}\right)$. To shift the reaction to the right, excess steam is used $\left(\mathrm{H}_{2} \mathrm{O} / \mathrm{CH}_{4} \approx 3\right)$. Excess steam helps also reduce catalyst coking and increase hydrogen product by favoring the reaction $\mathrm{CO}+\mathrm{H}_{2} \mathrm{O} \rightarrow \mathrm{CO}_{2}+\mathrm{H}_{2}$. For economic reasons, high pressure is used (30 atm) although this is against thermodynamic principles which calls for decreasing pressure to increase conversion.

\section{Catalysts for Steam Reforming}

Typical metals used in steam reforming catalysts include noble metals such as rhuthenium, rhodium, palladium, platinum, as well as other metals such as nickel and cobalt. All of these metals are able to dissociatively adsorb the hydrocarbons as well as produce carbon dioxide and hydrogen to some degree. The noble metals are typically more active than nickel and cobalt. However, they also are much more expensive. Due to its low cost and high activity compared to cobalt, nickel is the 
metal of choice for the steam reforming of hydrocarbons. To reduce the problem of coking, alkaline earth oxides such as calcium and magnesium are usually added to the catalyst formulation. Recent research include the study of the effect of adding silver [6 ] and cerium and zirconium oxides [7].

The effect of $\mathrm{Ag}$ loading (0.1-0.6 wt.\%) on the physicochemical properties and catalytic behavior of $\mathrm{Al}_{2} \mathrm{O}_{3}$-supported $\mathrm{Ni}$ catalysts on steam reforming of methane was studied in reference [6]. In reference [7]a series of Ni/SBA-15 catalysts with $\mathrm{Ni}$ contents ranging from $5 \mathrm{wt} \%$ to $20 \mathrm{wt} \%$ as well as $10 w t \% N i / 10 w t \% \mathrm{Ce}_{x} \mathrm{Zr}_{1} \mathrm{x}: \mathrm{O}_{2} / \mathrm{SBA}-15(\mathrm{x}=0,0.5,1)$ were prepared. The results indicated that both the Ni/SBA-15 and the Ni/Ce $\mathrm{Zr}_{1} ; \mathrm{O}_{2} / \mathrm{SBA}-15$ catalysts had good catalytic activities at atmospheric pressure. The $10 \mathrm{wt} \% \mathrm{Ni} / \mathrm{SBA}-15$ catalyst exhibited excellent stability at $800{ }^{\circ} \mathrm{C}$ for time on stream of $740 \mathrm{~h}$. After the reaction, carbon deposits were not formed on the surface of the catalyst. There existed a regular hexagonal mesoporous structure in the Ni/SBA-15 and the Ni/Ce $\mathrm{CZ}_{1_{1}} ; \mathrm{O}_{2} / \mathrm{SBA}-15$ catalysts. The nickel species and the $\mathrm{Ce}_{x} \mathrm{Zr}_{1}{ }_{1} ; \mathrm{O} 2$ component were all confined in the SBA-15 mesopores. The $\mathrm{Ce}_{\mathrm{x}} \mathrm{Zr}_{1}{ }_{1} ; \mathrm{O} 2$ could promote dispersion of the nickel species in the $\mathrm{Ni} / \mathrm{Ce}_{x} \mathrm{Zr}_{1} \times \mathrm{O}_{2} / \mathrm{SBA}-15$ catalysts. The catalyst is usually shaped in the form of a cylinder with multiple holes to increase the surface area of the catalyst.

\section{Catalytic Partial Oxidation}

$$
\mathrm{CH}_{4}+1 / 2 \mathrm{O}_{2} \rightarrow \mathrm{CO}+2 \mathrm{H}_{2} \quad \Delta H=-36 \mathrm{MJ} / \mathrm{kmol} \mathrm{CH} 4 \text { (exothermic) }
$$

Catalytic partial oxidation reaction is a less accepted commercial process to produce hydrogen. It is an exothermic reaction that consists of reacting methane with oxygen. The advantages of this reaction are that it has a quick response time, high reaction efficiency. In addition, the heat it produces usually can be transferred to a heat exchanger for other applications. Nevertheless, the disadvantages of this process are that it requires a high operating temperature, a high fuel/air ratio to proceed the combustion reaction, and at the end of reaction, the heat of the waste gas stream cannot be reused, resulting in poor overall energy efficiency.

\section{Catalysts for Partial Oxidation}

Noble metals such as $\mathrm{Ru}, \mathrm{Rh}$,and Ir catalyze methane partial oxidation. Less expensive transition element metals such as $\mathrm{Ni}$, Co,and $\mathrm{Fe}$ can also catalyze this reaction but to a lesser degree. Hayakawa et al [8 ] synthesized a highly active $\mathrm{Ca}$ $0.8 \mathrm{Sr} 0.2 \mathrm{Ti} 0.8 \mathrm{Ni} 0.2$ catalyst. In reference [9] a metallic nickel monolith was prepared from nickel sponge by sintering, followed by acid treatment, and further promoted with $\mathrm{CeO}_{2}-\mathrm{ZrO}_{2}$ through an impregnation method. The two monolithic catalysts were studied in the oxidative steam and $\mathrm{CO}_{2}$ reformings of methane. The metallic nickel monolith showed high methane conversion and high selectivities to syngas, which were further enhanced by the promotion of $\mathrm{CeO}_{2}-\mathrm{ZrO}_{2}$. The ratios of $\mathrm{H}_{2} / \mathrm{CO}$ can be adjusted by adding steam (or $\mathrm{CO}_{2}$ ) to increase the selectivity to $\mathrm{H}_{2}$ (or $\mathrm{CO})$. The catalysts exhibited good stability in the reactions. 


\section{Autothermal Reforming Process (ATR)}

In autothermal reforming, we integrate the exothermic hydrocarbon catalytic partial oxidation (CPO) and the endothermic steam methane reforming (SMR) ; the methane is partially burned with oxygen and the products are then passed over a Ni-based catalyst. In order to understand the fundamental behavior of ATR, it is essential to understand the characteristics of each process as well.

$$
\begin{array}{ll}
\mathrm{CH} 4+1 / 2 \mathrm{O} 2 \rightarrow \mathrm{CO}+2 \mathrm{H} 2 & \Delta H=-36 \mathrm{MJ} / \mathrm{kmol} \mathrm{CH} 4 \text { (exothermic) } \\
\mathrm{CH} 4+\mathrm{H} 2 \mathrm{O} \rightarrow \mathrm{CO}+3 \mathrm{H} 2 & \Delta H=206 . \mathrm{KJ} / \mathrm{mol} \mathrm{CH} 4 \text { (endothermic) }
\end{array}
$$

The process of ATR uses methane or liquid hydrocarbons as fuel that undergoes a reaction with steam or air in a single reactor. Since the ATR process consists of the combination of CPO and SMR, the balance of the specific heat for each reaction becomes a very distinctive characteristic of this process. This makes the whole process relatively more energy efficient since the heat produced from CPO can transfer directly to be used by SMR. Under an ideal operating condition with the precise amount of air, fuel and steam, the reaction's theoretical efficiency can even reach higher than conventional SMR process $(93.9 \%$ vs. $91.7 \%)$. With ATR technologies, conventional SMR plants can be improved by size and weight reduction, lower costs, faster starting time and improved transient-time. Furthermore, the ATR process is capable of using heavy hydrocarbons such as gasoline and diesel, which can make it more appealing marketwise. Due to the fact that ATR is the least developed process when compared to CPO and SMR processes, numerous scientist and engineers are putting all their effort into the development of this process. One of the more promising results is that by reducing allowable oxygen to carbon ratios and using newly developed catalysts, the operating temperature of the process is greatly reduced from the traditional operating temperature of $1,200 \mathrm{C}$ to 650-900 C. However, the problem of the development of ATR is that although it has a higher theoretical efficiency than the SMR, actual experiment results are still indicating SMR is more efficient.

\section{Catalysts for autothermal reforming}

The effects of adding small amounts of palladium to $\mathrm{Ni} / \mathrm{Y}-\mathrm{Al}_{2} \mathrm{O}_{3}$ catalysts for the autothermal reforming of methane in terms of activity, reducibility, capacity of repeated ignition and temperature profile of the reactor are described in reference [10]. The effect of different Pd sources was also studied. The Pd addition favors nickel reduction at lower temperatures. When the palladium is added as $\mathrm{PdCl}_{2}$ (PdNiAl-Cl) it exhibits a higher reduction temperature than when $\mathrm{Pd}\left(\mathrm{NO}_{3}\right)_{2}(\mathrm{PdNiAl}-\mathrm{N})$ is used, an this can be attributed to the formation of $\mathrm{Pd}_{x} \mathrm{Cl}_{y} \mathrm{O}_{z}$ species. Palladium strongly increases the activity of the $\mathrm{Ni}$ catalyst in autothermal reforming of methane , which is proportional to an increase in metal surface area. The addition of palladium to the catalyst also leads to a flatter temperature profile through the catalytic bed in the autothermal reforming of methane , and this is assigned to the high surface metal area of the catalyst Only PdNiAl-N catalyst catalyzes the autothermal reforming of methane without previous reduction, while the PdNiAl-Cl catalyst only catalyzes the methane combustion and the unpromoted catalyst was inactive. 


\section{Dry Reforming of Methane}

During the last two decades, there has been a fast growing attention and interest in the catalytic conversion of methane reforming with carbon dioxide reaction $\left(\mathrm{CO}_{2}+\mathrm{CH}_{4} \rightarrow 2 \mathrm{CO}+2 \mathrm{H}_{2}\right)$. The process known as Dry reforming of methane has an attractive course to generate synthesis gas which, is the most important step in the gas-to-liquid transformation, consists of hydrogen and carbon monoxide gases or/and their mixture with a desired ratio $\mathrm{H}_{2} / \mathrm{CO}$ close to unity [11-14]. Syngas is traditionally produced by highly endothermic steam reforming of natural gas. However, this process provides a high $\mathrm{H}_{2} / \mathrm{CO}$ ratio $(>3)$, which is not suitable for Fischer-Tropsch and methanol syntheses. Thus, research efforts have been directed towards obtaining syngas with a more suitable $\mathrm{H}_{2} / \mathrm{CO}$ ratio of 2 or lower via methane partial oxidation or by $\mathrm{CH}_{4} / \mathrm{CO}_{2}$ reforming. Partial oxidation of methane and $\mathrm{CO}_{2}$ reforming of methane have the potential to reduce the cost of syngas [15] and can be applied in solar energy storage [16] and/or $\mathrm{CO}_{2}$ utilization technologies [17].

Moreover, it is branded, that the reforming gases of methane and carbon dioxide are greenhouse gases, which contribute to the global warming potential of the earth's surface. For this end, the chemical utilization of natural gas and $\mathrm{CO}_{2}$, which are substances related to the environment and energy sources, has further intensified the weight of the reforming process. Unfortunately, no industrial technology for $\mathrm{CO}_{2}$ reforming of methane has yet been developed, because no effective, economic catalyst have been discovered. Past studies have focused on the development of catalytic processes for methane activation, in particular for the transformation of methane to syngas $[18,19]$.

Synthesis gas has been produced from the steam reforming of methane (Eq. (4))

$\mathrm{CH}_{4}+\mathrm{H}_{2} \mathrm{O} \rightarrow \mathrm{CO}+3 \mathrm{H}_{2}, \Delta H=206 \mathrm{~kJ} / \mathrm{mol}$

And from dry reforming of methane (equation(6))

$\mathrm{CH}_{4}+\mathrm{CO}_{2} \rightarrow 2 \mathrm{CO}+2 \mathrm{H}_{2}, \Delta H=247 \mathrm{~kJ} / \mathrm{mol}$

In Eq. (4), the partial pressure ratio of steam to methane $\left(\mathrm{H}_{2} \mathrm{O} / \mathrm{CH}_{4}\right)$ is equal to 1 , however, in practical cases, the reaction has been carried out under higher $\mathrm{H}_{2} \mathrm{O} / \mathrm{CH}_{4}$. This is because carbon deposition occurred on the catalyst surface under low $\mathrm{H}_{2} \mathrm{O} / \mathrm{CH}_{4}$ condition. The composition of syngas in Eq. (4) is $\mathrm{H}_{2} / \mathrm{CO}=3$, therefore, the steam reforming is not appropriate for syngas production with $\mathrm{H}_{2} / \mathrm{CO}=2$ or 1 . Dry reforming of methane can contribute to the production of $\mathrm{CO}$-rich syngas as shown in Eq. (6) because the composition of syngas in Eq. (5) is $\mathrm{H}_{2} / \mathrm{CO}=1$. The combination of dry reforming with steam reforming can adjust the syngas composition. It has been pointed out that the one of the problems is carbon deposition on the catalyst surface in the production of syngas with low $\mathrm{H}_{2} / \mathrm{CO}$, which results in the catalyst deactivation, plugging of the reactor, and breakdown of the catalyst granules [20-22]. It has also been reported that there are two routes for the formation of deposited carbon. One is methane decomposition $\left(\mathrm{CH}_{4} \rightarrow \mathrm{C}+2 \mathrm{H}_{2}\right)$ and the other is $\mathrm{CO}$ disproportionation $\left(2 \mathrm{CO} \rightarrow \mathrm{C}+\mathrm{CO}_{2}\right)$ [20-22]. 


\section{Catalysts for Dry Reforming}

Several catalysts have already been studied and the group VIIIB elements are the most active, such as, the noble metal $\mathrm{Rh}, \mathrm{Pt}, \mathrm{Ru}$ and non-noble nickel [23-26]. Attempts to overcome this limitation have focused on the development of improved catalysts. Nickel is considered as most promising catalyst for $\mathrm{CO}_{2} / \mathrm{CH}_{4}$ reforming, due to its low cost, Ni-based catalysts are often preferred. However, this reaction is accompanied by a negative effect of carbon deposit formation leading to fast deactivation of Ni/oxidic support catalysts. The catalyst deactivation is the main hindrance for a catalyst to be considered for an industrial application, the two most known causes are: coke deposition and sintering of the metallic active phase. Most of the investigators agree that coke formation is the main cause of deactivation. Carbon deposition results from two reactions, Boudouard reaction $\left(2 \mathrm{CO} \rightarrow \mathrm{C}+\mathrm{CO}_{2}\right)$ and/or methane decomposition $\left(\mathrm{CH}_{4} \rightarrow \mathrm{C}+2 \mathrm{H}_{2}\right)$. The type and the nature of coke formed depend on the metal and in many cases on the support used.

One of possible routes for the improvement of nickel catalyst stability was the modification of the support. Addition of a rare earth oxide to Ni-based catalysts was an effective way for suppression of coke. Krylov et al. [27 ] found that doping a Ni catalyst with manganese oxide reduce carbon formation. Recently, Li et al. [28] reported that the addition of $\mathrm{La}(\mathrm{Ac})_{3}$ to $\mathrm{Ni} / \mathrm{BaTiO}_{3}$ catalyst hindered the aggregation of $\mathrm{Ni}_{0}$ particles and obtained size of $\mathrm{Ni}$ particles necessary for suppressing carbon deposition. Goldwasser et al. [29] described that no significant coke was formed even after time on stream of $120 \mathrm{~h}$ and the conversion of $\mathrm{CH}_{4}$ and $\mathrm{CO}_{2}$ over the perovskite-like, Sm1.8Ca0.2RuNiO5.8 increased. Zhang et al [30] also found that doping of the rare earth (La3+) in Ni/ZSM-5 not only enhanced the stability of catalyst, but also increased the catalytic activity. The fact mentioned above demonstrated that modification of Ni-based catalysts with rare earth oxides was effective in preventing coke formation. Zhang et al.[31] studied $\mathrm{CO}_{2}$ reforming of methane over $\mathrm{Ni} / \mathrm{Sm}_{2} \mathrm{O}_{3}-\mathrm{CaO}$ catalyst prepared by a sol-gel technique.

Bimetallic surface usually exhibits unique compositions that can deviate significantly from the bulk. One of the major driving forces for this behavior is surface segregation. The migration of a particular species to the surface of an alloy in turn will affect such properties as: adsorption, oxidation, reduction and catalytic performance. The dry reforming group at chemical engineering department, king saud university [32-35] has been carrying an extensive study in preparing and testing nickel based catalyst for dry reforming of methane with carbon dioxide. This is considered as a mean of additional utilization of methane which is available in Saudi Arabia in large quantities as one of the national resources (natural gas either alone or associated with oil). This also represents a mean of carbon dioxide utilization. The studies involve using different supports such as alumina with high and low surface area, silica, titania alumina mixture , titania and $\mathrm{Zr}$-Oxide as well as using different loading of nickel , using different promoters such as $\mathrm{Ce}, \mathrm{CO}, \mathrm{MO}, \mathrm{Nb}, \mathrm{SN}, \mathrm{Ca}$ and $\mathrm{Sb}$, calcination temperature, activation of prepared catalysts and stability study for the best catalyst. The prepared catalysts that have been tested until now were tested in micro reactor at atmospheric pressure using three different temperatures that range from 500$575 \mathrm{C}$ and total feed flow rate of $6-30 \mathrm{ml} / \mathrm{min}$. 
The activation procedure was carried once for each catalyst used inside the reactor by passing hydrogen at a rate of $20 \mathrm{ml} / \mathrm{min}$. for a period of two hours followed by nitrogen flow for half an hour.The results of the tests involve the effect of the preparation conditions on the activity of the catalyst (methane conversion or/and carbon dioxide conversion) as well as hydrogen selectivity in the produced synthesis gas. Based on the activity and stability studies, it was found that alumina with high surface area is the best support and $\mathrm{Ce}$ is the best promoter among the additives used in this study. The optimum calcination temperature was found to be $600 \mathrm{C}$. It was also noticed that activation procedure is a must in order for the reaction to take place. Another study was carried out [36] to investigate the effect of changing the ratio of the feed gases methane to carbon dioxide, seven different ratio of methane to carbon dioxide that range from $0.25-4.0$ were used The results indicate that changing the ratio of methane to carbon dioxide led to a decrease in methane conversion, increase in carbon dioxide conversion and decrease in hydrogen yield at each temperature used.As temperature increases the conversion of both gases and hydrogen yield increase. Changing total feed flow rate has no effect on either conversion or hydrogen yield

\section{Chemical looping reforming}

Chemical loop combustion (CLC) Figure (1)[37] is a novel approach to oxidize fuels. Oxygen is delivered to the fuel by a solid oxygen carrier, for example a metal oxide (MeO). Flameless oxidation takes place at moderate temperature $\left(750{ }^{\circ} \mathrm{C}\right.$ or higher). There is no mixing between combustion air and fuel, so produced $\mathrm{CO}_{2}$ is not diluted with $\mathrm{N}_{2}$ or $\mathrm{O}_{2}$. The metals tested include copper, nickel, manganese and iron.

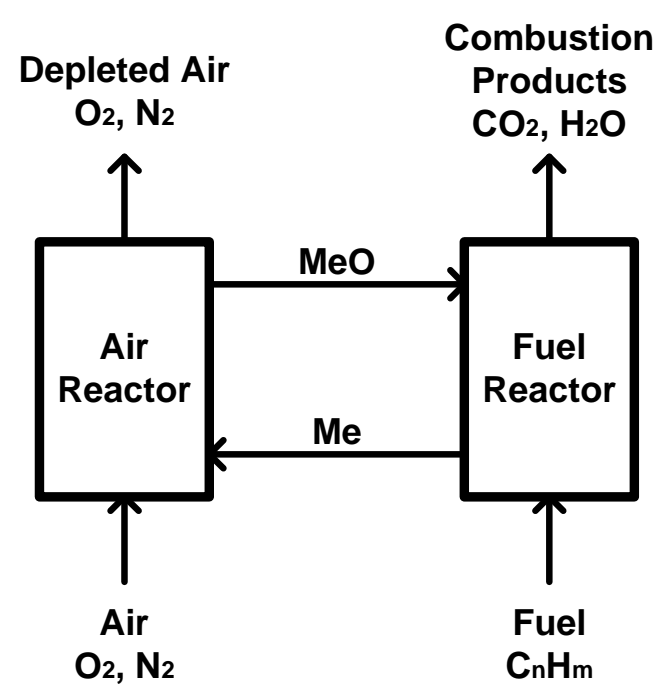

Figure (1) Chemical loop combustion 
Instead of full conversion of fuel, as in chemical-looping combustion, the same cycle is used for partial oxidation of the fuel, to produce a syngas, suitable for production of hydrogen and separation of $\mathrm{CO} 2$. This is called chemical loop reforming Figure (2)

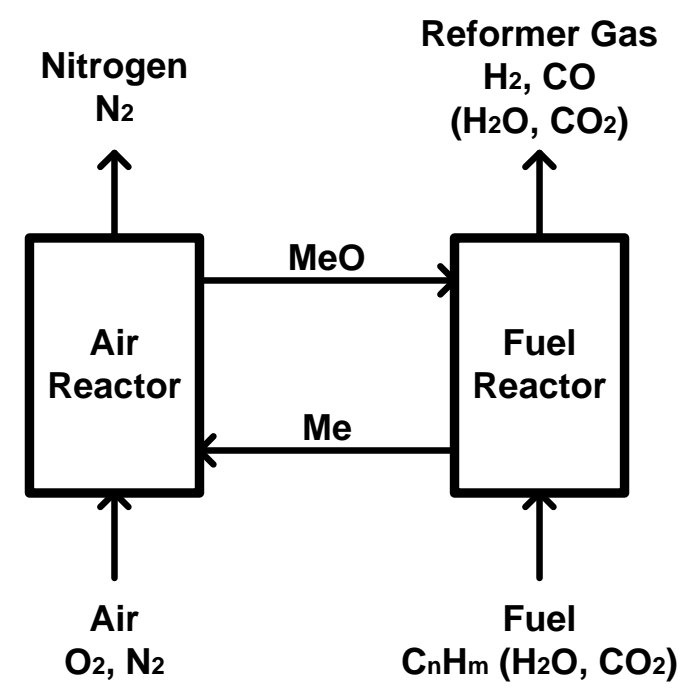

Figure (2) Chemical loop reforming

\section{Tri- Reforming of Methane}

Tri-reforming [38] is a novel process concept proposed for effective conversion and utilization of $\mathrm{CO}_{2}$ in the flue gases from fossil fuel-based power plants (C. Song, Chemical Innovation, 2001, 31, 21-26). The $\mathrm{CO}_{2}, \mathrm{H}_{2} \mathrm{O}$, and $\mathrm{O}_{2}$ in the flue gas need not be pre-separated because they will be used as co-reactants for tri-reforming of natural gas. The tri-reforming is a synergetic combination of $\mathrm{CO}_{2}$ reforming, steam reforming, and partial oxidation of natural gas. It can produce synthesis gas $\left(\mathrm{CO}+\mathrm{H}_{2}\right)$ with $\mathrm{H}_{2} / \mathrm{CO}$ ratios $(1.5-2.0)$ and could eliminate carbon formation which is a serious problem in the $\mathrm{CO}_{2}$ reforming of methane. These two advantages have been demonstrated by a laboratory experimental study of tri-reforming at $850^{\circ} \mathrm{C}$. Both thermodynamic analysis and the experimental testing in a fixed-bed flow reactor showed that over $95 \% \mathrm{CH}_{4}$ conversion and over $80 \% \mathrm{CO}_{2}$ conversion can be achieved by using certain supported transition metal catalysts such as Ni supported on an oxide substrate. The feedstock can be either natural gas or flue gas of power plants, or $\mathrm{CO}_{2}$-rich natural gas

\section{Catalysts for tri-reforming}

Lee et al [39] reported the results obtained on tri-reforming of methane over the $\mathrm{Ni} / \mathrm{ZrO}_{2}$ based catalyst in order to restrain the carbon deposition and to evaluate the catalytic performance. Results of tri-reforming of $\mathrm{CH}_{4}$ by three catalysts $(\mathrm{Ni} / \mathrm{Ce}-\mathrm{ZrO}$, $\mathrm{Ni} / \mathrm{ZrO}_{2}$ and Haldor Topsoe $\mathrm{R} 67-7 \mathrm{H}$ ) are showed that the coke on the reactor wall and the surface of catalyst were reduced dramatically. It was found that the weak acidic site, basic site and redox ability of $\mathrm{Ce}-\mathrm{ZrO}_{2}$ play an important role in trireforming of methane conversion. Carbon deposition depends not only on the nature of support, but also on the oxidant as like steam or oxygen. Therefore, the process 
optimization by reactant ratios is important to manufacture the synthesis gas from natural gas and carbon dioxide.

Song and Pan [40]showed that the type and nature of catalysts have a significant impact on $\mathrm{CO}_{2}$ conversion in the presence of $\mathrm{H}_{2} \mathrm{O}$ and $\mathrm{O}_{2}$ in tri-reforming in the temperature range of $700-850{ }^{\circ} \mathrm{C}$. Among all the catalysts tested for tri-reforming, their ability to enhance the conversion of $\mathrm{CO}_{2}$ follows the order of $\mathrm{Ni} / \mathrm{MgO}>\mathrm{Ni} / \mathrm{MgO} / \mathrm{CeZrO}>\mathrm{Ni} / \mathrm{CeO}_{2} \approx \mathrm{Ni} / \mathrm{ZrO}_{2} \approx \mathrm{Ni} / \mathrm{Al}_{2} \mathrm{O}_{3}>\mathrm{Ni} / \mathrm{CeZrO}$. The higher $\mathrm{CO}_{2}$ conversion over $\mathrm{Ni} / \mathrm{MgO}$ and $\mathrm{Ni} / \mathrm{MgO} / \mathrm{CeZrO}$ in tri-reforming may be related to the interaction of $\mathrm{CO}_{2}$ with $\mathrm{MgO}$ and more interface between $\mathrm{Ni}$ and $\mathrm{MgO}$ resulting from the formation of $\mathrm{NiO} / \mathrm{MgO}$ solid solution. Results of catalytic performance tests over $\mathrm{Ni} / \mathrm{MgO} / \mathrm{CeZrO}$ catalysts at $850^{\circ} \mathrm{C}$ and $1 \mathrm{~atm}$ with different feed compositions confirm the predicted equilibrium conversions based on the thermodynamic analysis for tri-reforming of methane. Kinetics of tri-reforming were also examined. The reaction orders with respect to partial pressures of $\mathrm{CO}_{2}$ and $\mathrm{H}_{2} \mathrm{O}$ are different over $\mathrm{Ni} / \mathrm{MgO}, \mathrm{Ni} / \mathrm{MgO} / \mathrm{CeZrO}$, and $\mathrm{Ni} / \mathrm{Al}_{2} \mathrm{O}_{3}$ catalysts for tri-reforming.

Kang et al. [41] carried out the tri-reforming reaction over $\mathrm{NiO}-\mathrm{YSZ}-\mathrm{CeO}_{2}$ catalyst to produce a synthesis gas from greenhouse gases like $\mathrm{CH}_{4}$ and $\mathrm{CO}_{2}$ contributing to the greenhouse effect. It was found that the tri-reforming reaction was more favorable than the dry reforming reaction for the production of synthesis gas. It was also observed that $\mathrm{NiO}-\mathrm{YSZ}-\mathrm{CeO}_{2}$ catalyst showed higher catalytic activity and stability than commercial Holder Topsoe (HT) and Imperial Chemical Industries (ICI) catalysts in the tri-reforming of $\mathrm{CH}_{4}$. The results suggest that the tri-reforming process can be applied to the production of high-valued chemicals and the fuel processor of solid oxide fuel cell (SOFC) and molten carbonate fuel cell (MCFC) systems.

The tri-reforming of methane over $\mathrm{Ni} / \mathrm{Mg}_{x} \mathrm{Ti}_{1-} \mathrm{O}$ catalysts was carried out in a fixed bed flow reactor by Jiang et al.[42]. The conversions of $\mathrm{CH}_{4}$ and $\mathrm{CO}_{2}$ can respectively be achieved as high as above $95 \%$ and $83 \%$ over $\mathrm{Ni} / \mathrm{Mg}_{0.75} \mathrm{Ti}_{0.25} \mathrm{O}$ catalyst under the reaction conditions. The activity of $\mathrm{Ni} / \mathrm{Mg}_{0.75} \mathrm{Ti}_{0.25} \mathrm{O}$ and $\mathrm{Ni} / \mathrm{Mg}_{0.5} \mathrm{Ti}_{0.5} \mathrm{O}$ did not decrease for a reaction period of $50 \mathrm{~h}$, indicating their rather high stability. The experimental results showed that the nature of support, the interaction between metal and support, and the ability to be reduced played an important role in improving the stability of catalysts. Thermal Distribution in the catalyst bed during the tri-reforming reaction. Thermal distribution in catalyst bed was investigated by Jiang et al. [ 43] for the fixed-bed tri-reforming of methane over $\mathrm{Ni} / \mathrm{Al}_{2} \mathrm{O}_{3}$ under atmospheric pressure, $750-950^{\circ} \mathrm{C}$, and space velocity $\left(\mathrm{S}_{\mathrm{V}}\right)$ of $2000-20000 \mathrm{~h}^{-1}$. The effects of the furnace temperature $\left(t_{\mathrm{f}}\right)$, the space velocity, and the feed stock composition on the thermal distribution were examined. The results indicated that the temperature gradient of the catalyst bed in methane trireforming is smaller than that in methane partial oxidation. The temperature near the inlet of the catalyst bed $\left(t_{\max }\right)$ is $80^{\circ} \mathrm{C}$ higher than $t_{\mathrm{f}}$ when the feed composition $\mathrm{n}\left(\mathrm{CH}_{4}\right) / \mathrm{n}\left(\mathrm{CO}_{2}\right) / \mathrm{n}\left(\mathrm{H}_{2} \mathrm{O}\right) / \mathrm{n}\left(\mathrm{O}_{2}\right)=50 / 12.5 / 12.5 / 25$ (by mol) and the space velocity $S_{V}=$ $20000 \mathrm{~h}^{-1}$, whereas the temperature near the outlet of the catalyst bed is close to $t_{\mathrm{f}}$. The temperature difference between the inlet and the furnace $\Delta t_{\max }=t_{\max }-t_{\mathrm{f}}$ ) 
increases with the space velocity $\Delta t_{\max }=30^{\circ} \mathrm{C}$ at $2000 \mathrm{~h}^{-1}, \Delta t_{\max }=80^{\circ} \mathrm{C}$ at 20000 $\mathrm{h}^{-1}$ ). No distinct hot spot is observed near the catalyst bed inlet when there is no oxygen in feed. Under specific condition, the lowest temperature in the catalyst bed $\left(t_{\text {min }}\right)$ is about $30-40^{\circ} \mathrm{C}$ lower than $t_{\mathrm{f}}$. According to the thermal distribution, the catalyst bed can then be divided into three zones: oxygen adequate zone, oxygen inadequate zone, and oxygen absent zone. Methane reforming proceeds in the first and second zones, while methane combustion proceeds only in the first zone and partial oxidation of methane proceeds only in the second zone.

\section{Co-production of Chemicals to reduce $\mathrm{CO} 2$ emissions}

Halmann and Steinfeld [44] suggested combining the carbothermic reduction of iron oxide with the partial oxidation of the carbon source, an overall thermo-neutral process that can be designed for the co-production of iron and syngas rich in $\mathrm{CO}$. Water-gas shift of $\mathrm{CO}$ to $\mathrm{H}_{2}$ enables the production of useful syngas. The reaction process heat, or the conditions for thermo-neutrality, are derived by thermochemical equilibrium calculations. The thermodynamic constraints are determined for the production of syngas suitable for methanol, hydrogen, or ammonia synthesis. The environmental and economic consequences are assessed for large-scale commercial production of these chemical commodities. In the case of the tri-reforming of flue gas from coal-fired power stations to form syngas, the predicted fuel savings and $\mathrm{CO}_{2}$ emission avoidance by the conversion to methanol would be 20 and $70 \%$, to hydrogen 17 and 29\%, and to ammonia 74 and 30\%, respectively. In the case of the co-production of iron and methanol, the predicted fuel saving and $\mathrm{CO}_{2}$ emission avoidance would amount to $27 \%$ and $50 \%$, respectively, relative to the conventional separate production of the same amounts of these two commodities. For the coproduction of iron and hydrogen, the corresponding fuel saving and $\mathrm{CO}_{2}$ emission avoidance would reach $62 \%$ and $18 \%$. The fuel saving by the co-production of iron and ammonia would be $19 \%$. Preliminary evaluations with natural gas, coke, or coal as carbon source indicate that such combined processes should be economically competitive. The production of ammonia in the above processes seems particularly attractive, as it consumes the nitrogen in the flue gases $\mathrm{Xu}$ et al. [45] identified fourteen new energy-efficient and environmentally acceptable catalytic processes that can use excess high-purity carbon dioxide as a raw material available in a chemical production complex.

A methodology for selecting the new energy-efficient processes was developed based on process operating conditions, energy requirements, catalysts, product demand and revenue, market penetration and economic, environmental and sustainable costs. Based on the methodology for selecting new processes, 20 were identified as candidates for new energy efficient and environmentally acceptable plants. These processes were simulated using HYSYS, and a value-added economic analysis was evaluated for each process. The optimum structure had seven new processes including acetic acid, graphite, formic acid, methylamines, propylene and synthesis gas production. Multicriteria optimization has been used with Monte Carlo simulation to determine the sensitivity of prices, costs, and sustainability credits/cost to the optimal structure of a chemical production complex. 


\section{CONCLUSIONS}

According to this review, we are going to see power plants using a mixture of oxygen and carbon dioxide with flue gas recycle to burn the fuel and these plants could be connected to chemical plants complex that uses the carbon dioxide in the flue gases as feedstock. The process of reforming of natural gas will be the heart of these chemical plants complex. Alternatively these flue gases could be sequestered underground or under the seafloor. More integration between chemical plants will take place to reduce the carbon dioxide emissions. More efficient methods to capture $\mathrm{CO} 2$ from dilute gases will be developed. More research will be carried out for carbon dioxide utilization.

\section{ACKNOWLEDGMENT}

The authors would like to thank Sabic Company for supporting Scientific research , specially the garnt given through project $14 / 25$ and 19/26 that is the base for this paper. The thank is also extended to Dean ship of research and research center at college of Engineering for supporting this research.

\section{REFERENCES}

[1] X. Xu, J. M. Andresen, C. Song, B. Miller, and A. W. Scaroni, Energy \& Fuels, 16 (6), $1463-1469,2002$

[2] CHUNSHAN SONG, Catalysis Today, Volume 115, Issues 1-4, 30 June 2006, Pages 2-32.

[3] Stephen K. Ritter, Chemical \& Engineering News,April 30, 2007 ,Volume 85, Number 18 ,pp. 11-17

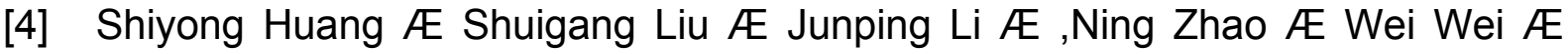
Yuhan Sun, Catalysis Letters,118,\#3-4,p290-294

[5] A. P. E. York, T. Xia, M. L. H. Green, and J. B. Claridge, Catalysis Review, 49(2007), p511-560

[6] N.V. Parizotto ${ }^{\underline{a}}$, K.O. Rocha $\underline{b}$, S. Damyanova ${ }^{\underline{c}}$, F.B. Passos ${ }^{\underline{d}}$, D. Zanchet ${ }^{\underline{e}}$, C.M.P. Marques ${ }^{a}$ and J.M.C. Buen,Applied Catalysis A: General ,Volume 330, 10 October 2007, Pages 12-22

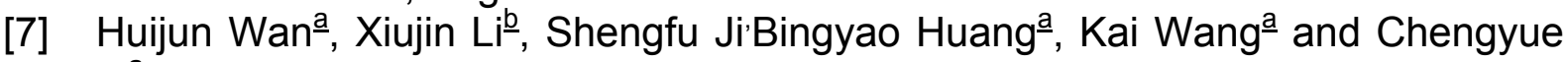
Lì-, Journal of Natural Gas Chemistry, Volume 16, Issue 2, June 2007, Pages 139-147

[8] T. Hayakawa, A.G. Anderson, M. Shimizu, K. Suzuki, and K. Takehira (1993), Catalysis Letters, 22,p 307

[9] Joelmir A.C. Dias and José M. Assaf, Applied Catalysis A: General, Volume 334, Issues 1-2, 1 January 2008, Pages 243-250

[10] Yunhua $\mathrm{Li}^{1}$, Yaquan Wang ${ }^{1}{ }^{*}$, Xuebin Hong ${ }^{1}$, Zhaoguang Zhang ${ }^{1}$, Zhiping Fang $^{2}$, YuPan ${ }^{2}$, Yanbo Lu ${ }^{2}$, Zhongqi Han, AIChE J.,52,\#12,p4276-4279

[11] A. Lewicki, T. Paryjczak, W.K. Jóźwiak and J.M. Rynkowski, Wiad. Chem. 56 (2002), p. 279.

[12] Y.H. Hu and E. Ruchenstein. Catal. Rev. Sci. Eng. 44 (2002), p. 423.

[13] M. Bradford and M. Vannice, Catal. Rev. Sci. Eng. 41 (1999), p. 1

[14] Y.G. Chen, K. Tomishige, K. Yokoyama, Y.K. Fajimoto, Appl. Catal. A: General, 165, 335 (1997). 5-9,11-13, 
[15] A.T. Ashcroft, A.K. Cheetham, J.S. Foord, M.L.H. Green, C.P. Grey, A.J. Murrel, P.D.F. Veron, Nature 344 (1990) 319.

[16] J. Nakamura, K. Aikawa, K. Sato, T. Uchijima, Catal. Lett. 25 (1994) 265.

[17] T. Kodama, T. Koyanagi, T. Shimizu, Y. Kitayama, Energy Fuels 15 (2001) 60.

[18] J.P. van Hook, Catal. Rev. Sci. Eng. 21 (1981) 1.

[19] A.T. Ashcroft, A.K. Cheetham, J.S. Foord, M.L.H. Green, C.P. Grey, A.J. Murrel, P.D.F. Veron, Nature 344 (1990) 319.

[20] J.R. Rostrup-Nielsen, in: J.R. Anderson, M. Boudart (Eds.), Catalysis Science and Technology, vol. 5, Springer-Verlag, New York, 1984.

[21] C.H. Bartholomew, Catal. Rev. Sci. Eng. 24 (1982) 67.

[22] D.L. Trimm, Catal. Rev. Sci. Eng. 16 (1977) 155.

Ref (D65)14-20

[23] J.H. Edwards, A.M. Maitra, Fuel Process Technol. 42 (1995) 269.

[24] J.H. Bitter, K. Seshan, J.A. Lercher, J. Catal. 171 (1997) 279.

[25] M.C.J. Bradford, M.A. Vannice, J. Catal. 183 (1999) 69.

[26] B.S. Liu, C.T. Au, Catal. Lett. 85 (2003) 165.

[27] O. V. Krylov, A. K. Mamedov, and S. R. Mirabekova (1995), Industrial and Engineering Chemistry Research,134,p 474

[28] X.C. Li, M. Wu, Z.H. Lai, F. He, Appl. Catal. A 290 (2005) 81.

[29] M.R. Goldwasser, M.E. Rivas, E. Pietri, et al., Appl. Catal. A 255(2003) 45.

[30] W.D. Zhang, B.S. Liu, C. Zhu, Y.L. Tian, Appl. Catal. A 292 (2005)138.

[31] W.D. Zhang, B.S. Liu, Y.L. Tian, Catalysis Communications 8 (2007) 661-667

[32.] Fakeeha, A.H., Soliman, M.A. and AL Fatish, A.S, proceeding of $2^{\text {nd }}$ European Hydrogen Energy conference, held at Zaragoza , Spain , September 22-25, 2005.

[33] Fakeeha, A.H., Soliman, M.A. and AL Fatish, A.S., $3^{\text {rd }}$ International Conference On chemical\& Environmental Engineering, Military Technical College, Cairo, Egypt ,16-18 May 2006.

[34] Fakeeha, A.H.; Al-Fatish A; Soliman M.; Ibrahim A.,The seventh International Conference on Chemistry In Industry, Manama, Kingdom of Bahrain, March 26-28, 2007.

[35] Fakeeha, A.H., AL Fatish, A.S., Soliman, M.A. and Ibrahim, A.A, First AfroAsian Conference on Advanced Material Science and Technology, Cairo Egypt, 13-16 Nov. 2006.

[36] Fakeeha, A.H., AL Fatish, A.S., Soliman, M.A. and Ibrahim, A.A.; $16^{\text {th }}$ World Hydrogen Energy Conference , Lyon , France, 13-16, June 2006.

[37] Magnus Rydén' , Anders Lyngfelt and Tobias Mattisson, Magnus Rydén', Fuel, Volume 85, Issues 12-13,p736-747

[38] Chunshan Song, Wei Pan, Srinivas T. Srimat, Jian Zheng, Yan Li, Yu-He Wang, Bo-Qing $\mathrm{Xu}$ and Qi-Ming Zhu, Studies in Surface Science and Catalysis, Volume 153, 2004, Pages 315-322

[39] Seung-Ho Lee, Wonihl Cho, Woo-Sung Ju, Young-Soon Baek, Jong-San Chang and Sang-Eon Park, Studies in Surface Science and Catalysis, Volume 153, 2004, Pages 189-192

[40] Chunshan Song and Wei Pan, Catalysis Today, Volume 98, Issue 4, 14 December 2004, Pages 463-484

[41] Jung Shik Kang, Dae Hyun Kim, Sang Deuk Lee, Suk In Hong and Dong Ju Moon Applied Catalysis A: General, Volume 332, Issue 1, 1 November 2007, Pages 153-158 
[42] Hongtao Jiang, Huiquan Li, Hongbin $\mathrm{Xu}$ and $\mathrm{Yi}$ Zhang , Fuel Processing Technology, Volume 88, Issue 10, October 2007, Pages 988-995

[43] Hong-tao JIANG, Hui-quan LI and Yi ZHANG , Journal of Fuel Chemistry and Technology, Volume 35, Issue 1, February 2007,Pages 72-78

[44] M. Halmann and A. Steinfeld ,Energy, Volume 31, Issue 15, December 2006, Pages 3171-3185

[45] Aimin Xu , Sudheer Indala, Thomas A. Hertwig, Ralph W. Pike, F. Carl Knopf, Carl L. Yaws,Jack R. Hopper,Clean Techn Environ Policy, Vol.7,p 97-115 (2005) 